\title{
FREEDOM OF ASSOCIATION
}


THE UNIVERSITY CENTER FOR HUMAN VALUES SERIES

AMY GUTMANN, EDITOR 


\section{FREEDOM OF ASSOCIATION}

Edited by Amy Gutmann

PRINCETON UNIVERSITY PRES S

PRINCETON, NE W JER S E Y 
Copyright (C 1998 by Princeton University Press

Published by Princeton University Press, 41 William Street, Princeton, New Jersey 08540 In the United Kingdom: Princeton University Press, Chichester, West Sussex

All Rights Reserved

\section{Library of Congress Cataloging-in-Publication Data}

Freedom of association / edited by Amy Gutmann.

p. $\quad \mathrm{cm} . \quad$ - (The University Center for Human Values series)

Includes bibliographical references and index.

ISBN 0-691-05758-3 (cloth : alk. paper). — ISBN 0-691-05759-1 (pbk. : alk. paper)

1. Freedom of association-United States. 2. Associations, institutions, etc.-United States. I. Gutmann, Amy. II. Series.

KF4778.F74 1998

$344.73^{\prime} 0414-\mathrm{dc} 21$

CIP

This book has been composed in Janson

Princeton University Press books are printed on acid-free paper and meet the guidelines for permanence and durability of the Committee on Production Guidelines for Book Longevity of the Council on Library Resources

http://pup.princeton.edu

Printed in the United States of America

$\begin{array}{llllllllll}10 & 9 & 8 & 7 & 6 & 5 & 4 & 3 & 2 & 1\end{array}$

$\begin{array}{llllllllll}10 & 9 & 8 & 7 & 6 & 5 & 4 & 3 & 2 & 1\end{array}$

(Pbk.) 